\title{
ANNALS OF THE NEW YORK ACADEMY OF SCIENCES
}

VOLUME 244

April 15, 1975

\section{THE BIOLOGICAL ROLE OF PORPHYRINS AND RELATED STRUCTURES*}

\author{
Editor and Conference Chairman \\ Alan D. Adler

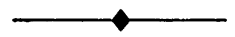 \\ CONTENTS
}

Preface. By Alan D. Adler $. . . \ldots \ldots \ldots \ldots \ldots \ldots \ldots \ldots \ldots, \quad v$

Part I. Hemeproteins: Ligation Phenomena

Reactions of Oxygen with Hemoglobin, Cytochrome $C$ Oxidase and Other Hemeproteins. By W. S. Caughey, C. H. Barlow, J. C. Maxwell,

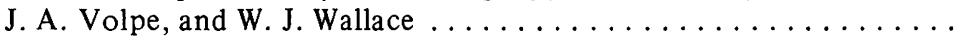

Measurement of Structural and Free Energy Changes in Hemoglobin by

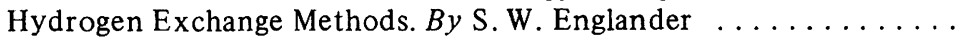

Leghemoglobin: The Role of Hemoglobin in the Nitrogen-Fixing Legume Root Nodule. By Jonathan B. Wittenberg, C. A. Appleby, F. J. Bergersen, and G. L. Turner $\ldots \ldots \ldots \ldots \ldots \ldots \ldots \ldots$

Thermodynamic Probes of Ferrimyoglobin Reactions. By George I. H.

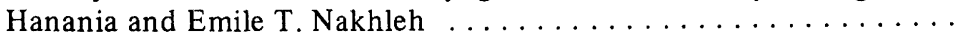

Ligand-Binding Reactions and Oxidation-Reduction Equilibria of Cytochrome C. By Abel Schejter, Irit Aviram, Rimona Margalit, and

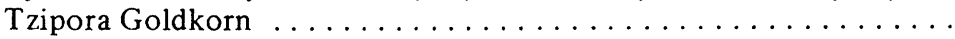

Oxygen Binding to Human Erythrocyte Cell Populations. By Bruce F. Cameron, Robert Zucker, and Donald R. Harkness ............ 60

\section{Part II. Hemeproteins: Redox Phenomena}

Conformational Changes in Hemoproteins of the Respiratory Chain. By

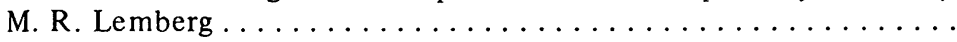

Chemistry of Peroxidase Intermediates. By Lowell P. Hager, Paul F. Hollenberg, Tsafrira Rand-Meir, Robert Chiang, and Dennis Doubek

A Model for the Halogenating Agent of Chloroperoxidase. By Robert K. DiNello, Kathleen Rousseau, and David Dolphin ...........

* This series of papers is the result of a conference entitled The Biological Role of Porphyrins and Related Structures, held by The New York Academy of Sciences on October $23,24,25$, and $26,1973$. 
Chemistry of Soluble and Membrane-Bound Cytochrome P-450. By Brenda Walker Griffin, Julian A. Peterson, Jürgen Werringloer, and Ronald W. Estabrook

Oxidation-Reduction Reactions of Hemeproteins. By C. E. Castro, Eleanor Bartnicki, Colin Robertson, Robert Havlin, Harry Davis, and

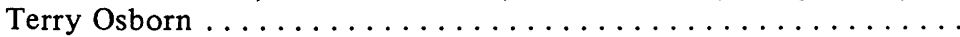

Heme Proteins and Model Compounds: Mössbauer Absorption and Emission Spectroscopy. By E. Münck and P. M. Champion . . . . . . .

On the Mechanism of the Reaction of Cytochrome Oxidase with Oxygen. By Britton Chance ..................

Manganese-Substituted Hemoglobin and Myoglobin. By B. M. Hoffman, Q. H. Gibson, C. Bull, R. H. Crepeau, S. J. Edelstein, R. G. Fisher,

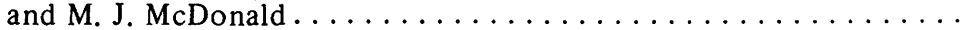

An Interim Report on Electronic Control of Oxygenation of Heme Proteins. By J. Peisach . . . . . . . . . . . . . . . . . . . . . . . .

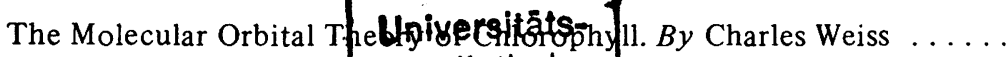
204

Part III. Chlosophylt Pthotosynthesis

Photosynthesis and Porphyrin Excited State Redox Reactions. By P. A.

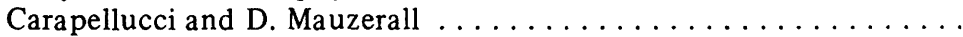

Endor Experiments on Chlorophyll and Bacteriochlorophyll in Vitro and in the Photosynthetic Unit. By G. Feher, A. J. Hoff, R. A.

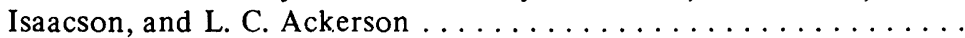

Models for Antenna and Reaction Center Chlorophylls. By James R. Norris, Hugo Scheer, and Joseph J. Katz . . . . . . . . . . . . .

Nature of Plant Chlorophylls in Vivo and Their Associated Proteins. By Leo P. Vernon and Sigrid M. Klein ................

Characterization of the Phototrap in Photosynthetic Bacteria. By Paul A. Loach, Mayfair (Chu) Kung, and Brian J. Hales . . . . . . . . .

The Interaction of Chlorophyll Dimers with Lutein. By S. Aronoff . . .

The Number of Biologically Possible Porphyrin Isomers. By S. Aronoff

Part IV. Mechanistic Aspects of Porphyrin Biosynthesis

The Regulation of Heme and Chlorophyll Synthesis in Bacteria. By June Lascelles . . . . . . . . . . . . . . . . . . . . . .

Porphyrin Synthesis: Some Particular Approaches. By David Shemin ..

Copyright, 1975, by The New York Academy of Sciences. All rights reserved. Except for brief quotations by reviewers, reproduction of this material in whole or in part by any means whatever is strictly prohibited without written permission from the publisher. 
Concerning the Biosynthesis of Vitamin $\mathrm{B}_{12}$. By A. Ian Scott .......

The Mechanism of Uroporphyrinogen Biosynthesis. By Benjamin Frydman, Rosalía B. Frydman, Aldonia Valasinas, Susana Levy, and Graciela Feinstein . . . . . . . . . . . . . . . . . . . . .

A Synthetic Approach to Some Tetrapyrranes. By S. F. MacDonald,

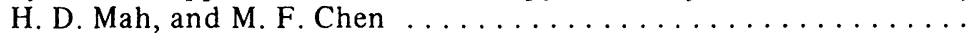

The Purification and Properties of Uroporphyrinogen I Synthases and Uroporphyrinogen III Cosynthase. Interactions between the Enzymes. By Masataka Higuchi and Lawrence Bogorad . . . . . . . . .

\section{Part V. Biomedical Aspects}

Effect of Lead and Genetic Factors on Heme Biosynthesis in the Human Red Cell. By S. Sassa, S. Granick, and A. Kappas . . . . . . .

The Clinical Biochemistry of the Human Hepatocutanéous Porphyrias in the Light of Recent Studies of Newly Identified Intermediates and Porphyrin Derivatives. By Lennox Eales, Yvonne Grosser, and William G. Sears . . . . . . . . . . . . . . . . . . . .

Mechanisms of Drug-Induced Porphyrin Biosynthesis. By Gerald S. Marks, Vincent Krupa, Frank Murphy, Hillel Taub, and Ronald A.

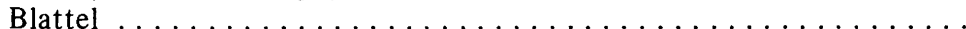

Comparative Aspects of Porphyria in Man and Animals. By Ephraim Y.

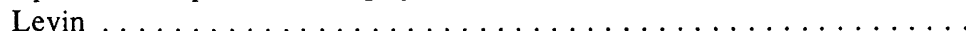

Porphyrins and Related Compounds as Photodynamic Sensitizers. By

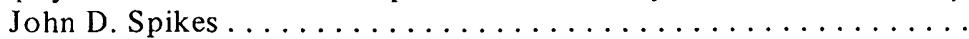

Heme Control on the Synthesis of Delta-Aminolevulinic Acid Synthetase in Cultured Chick Embryo Liver Cells. By Peter R. Sinclair

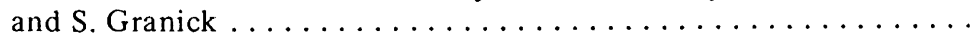

\section{Part VI. Physiological and Biological Aspects}

Present Status of the $d$-Urobilins. By Z. J. Petryka, M. Weimer, D. A. Lightner, M. Chedekel, F. A. Bovey, A. Moscowitz, and C. J. Watson

The Enzymatic Formation of Bilirubin. By R. Schmid and A. F.

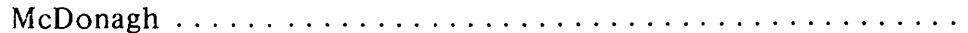

Thermal and Photochemical Reactions of Bilirubin IX- $\alpha$. By Antony F.

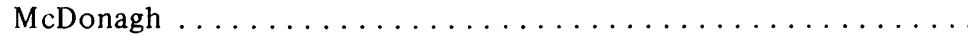

Red, White, and Blue Eggs as Models of Porphyrin and Heme Metabolism. By Samuel Schwartz, Betty D. Stephenson, Durriya H. Sarkar, and Miguel R. Bracho

The Later Stages of Porphyrin Biosynthesis. By A. H. Jackson and D. E.

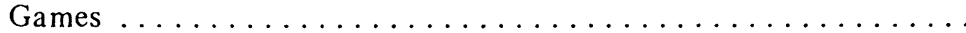


The Environment of Function of Liver and Red Blood Cells. By David

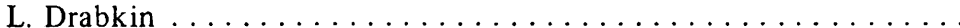

Porphyrin-Binding Proteins in Serum. By Ursula Muller-Eberhard and William T. Morgan

Heme Binding and Its Possible Significance in Heme Movement and Availability in the Cell. By L. G. Israels, B. Yoda, and B. A. Schacter

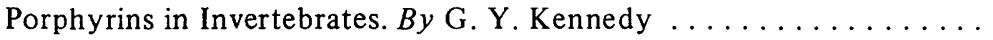

Tumor Localizers: Porphyrins and Related Compounds (Unusual Metalloporphyrins XXIII). By Minoru Tsutsui, Carl Carrano, and

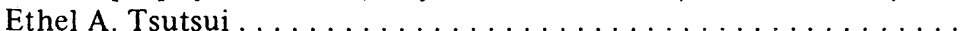

Porphyrins, Power, and Pollution. By Alan D. Adler, Veronika Váradi,

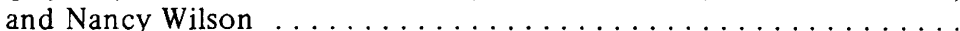

This monograph was aided by contributions from:

- EASTMAN KODAK COMPANY

- GENERAL FOODS CORPORATION

- HOFFMANN-LaROCHE, INC.

- MERCK SHARP \& DOHME RESEARCH LABORATORIES

- MERRELL-NATIONAL LABORATORIES

- SANDOZ PHARMACEUTICALS

- SCHERING CORPORATION

- SMITH KLINE \& FRENCH LABORATORIES

- WILSON LABORATORIES 


\title{
MODELS FOR ANTENNA AND REACTION CENTER CHLOROPHYLLS*
}

\author{
James R. Norris, Hugo Scheer, $\dagger$ and Joseph J. Katz \\ Chemistry Division \\ Argonne National Laboratory \\ Argonne, Illinois 60439
}

\section{INTRODUCTION}

The concept that chlorophyll molecules in green plants act cooperatively in photosynthetic units was first advanced by Emerson and Arnold. ${ }^{1}$ In this view, the large majority of the chlorophyll molecules act passively to harvest light quanta, which are then funneled to a few special chlorophyll molecules. In the photoreaction center, oxidizing and reducing capacity are generated. The nature and modus operandi of light-harvesting (antenna) chlorophyll and of reaction center chlorophyll are central problems of photosynthesis.

There have been two principle attacks on the structure and function of reaction center chlorophyll. The first relies on extensive degradation of photosynthetic organelles, whereas the second is based largely on a close comparison of well-defined in vitro systems with intact in vivo preparations or whole cells. The first may be termed an analytic, the second a synthetic approach to the problem. In the former procedure (for authoritative reviews, see Clayton ${ }^{2,3}$ ), photosynthetic tissue is treated with detergents, or detergent plus urea and alkali, and other like manipulations, ${ }^{4-8}$ to remove protein, lipid, and antenna chlorophyll. The residue from the dissolution treatment is then fractionated by combinations of ultracentrifugation, gel filtration, or other chromatographic techniques, with the objective to simplify the composition of the plant or bacterial photosynthetic apparatus so that structural details of the reaction center become evident. The identity of the "reaction center" so produced with the reaction center as it occurs in the plant (or photosynthetic bacterium) is established largely by visible absorption difference, circular dichroism, and electron spin resonance spectroscopy. The assumption that is implicit in most of this research is that the reaction center as a structural unit can, in fact, be unveiled in pristine form by suitable procedures. Not only must the possibility of destroying existing photoreactive chlorophyll be considered, but now it is also necessary to consider the possibility of creating chlorophyll species in the process of active center preparation similar to those that exist naturally. This latter eventuality has been largely ignored, but recent research on the spectral properties of chlorophyll-water adducts ${ }^{9-11}$ make the generation of additional "active center" chlorophyll a real possibility. There is good evidence to show that entities with "reaction center" spectral properties can, in fact, be generated in plant tissue by processes that insert water into antenna chlorophyll. Bacteriochlorophyll in situ appears to be hydrated to a larger exterit than is the case for chlorophyll $a$ in green plants, a circumstance that mitigates the importance of water insertion in the preparation of bacterial reaction

* Work performed under the auspices of the United States Atomic Energy Commission.

$\dagger$ Recipient of a grant from the Deutsche Forschungsgemeinschaft. 
centers. Thus, the relationship between in vivo reaction centers and in vitro isolates should be reexamined from this point of view. The presence of large amounts of bacteriopheophytin in reaction centers from Rhodopseudomonas spheroides, which might arise from pheophytinization during the isolation procedure, reinforces the desirability of further studies along these lines.

The other route to an understanding of active center and antenna chlorophyll is by a synthetic rather than an analytical approach. The optical and electron spin resonance properties of the active center in both intact green plants and photosynthetic bacteria have been well delineated. Can simple systems be formulated in the laboratory that possess the optical and magnetic resonance properties of in vivo active center and antenna chlorophyll? To apply such a procedure, the in vitro behavior of laboratory chlorophyll systems must be characterized in detail, and laboratory information that relates spectral properties with well-defined chlorophyll species can then be applied to the in vivo situation. This is basically the procedure that we have adopted. We will first describe briefly chlorophyll species that can be generated in the laboratory by chlorophyll-chlorophyll and by chlorophyll-ligand interactions. We will then show how the laboratory studies on chlorophyll and bacteriochlorophyll provide a firm basis for a structural interpretation of in vivo chlorophyll. In this communication we will focus attention primarily on what electron spin resonance (esr) and electron nuclear double resonance (endor) studies reveal about the nature of active center chlorophyll.

The synthetic approach we describe here has, to be sure, its own problems. With bacteriochlorophyll, we can produce remarkably simple systems in the laboratory that closely mimic the optical and esr properties of bacteriochlorophyll in situ. In the case of chlorophyll $a$, the laboratory studies so far provide a model for antenna chlorophyll and a good point of departure for inferences about the nature of reaction center chlorophyll in green plants. Despite its undoubted problems, the synthetic approach has considerable merit. The laboratory chlorophyll systems are well defined and, of great importance, spectroscopic observations on these can be more readily correlated with specific chlorophyll species of established structure. When comparisons are made as in our magnetic resonance work between laboratory systems and chlorophyll in situ in intact organisms, the role of artifacts surely must be minimized. While it is perhaps too optimistic to suppose that all of the fine structure of the photosynthetic apparatus will be revealed by these means, it is already evident that some of the salient features of the photosynthetic process have already yielded to it.

\section{CHLOROPHYLL SPECIES IN VITRO}

Various lines of investigation show chlorophyll to be a substance with a quite unusual combination of electron donor-acceptor properties. Studies on chlorophyll by infrared ${ }^{12,13}$ and ${ }^{1} \mathrm{H}$ and ${ }^{13} \mathrm{C}$ nuclear magnetic resonance $(\mathrm{nmr})$ spectroscopy, 12,14-16 electron spin resonance ${ }^{17}$ and endor spectroscopy, ${ }^{18}$ molecular weight determinations by vapor phase osmometry ${ }^{19}$ and ultracentrifugation, ${ }^{20}$ and visible absorption spectroscopy ${ }^{21}$ all are interpretable in these terms.

In the chlorophyll structure as usually written (FIGURE 1), the central magnesium atom is assigned a coordination number of 4 , in which the $\mathrm{Mg}$ atom is equally bonded to the four pyrrole nitrogen atoms. All laboratory investi- 


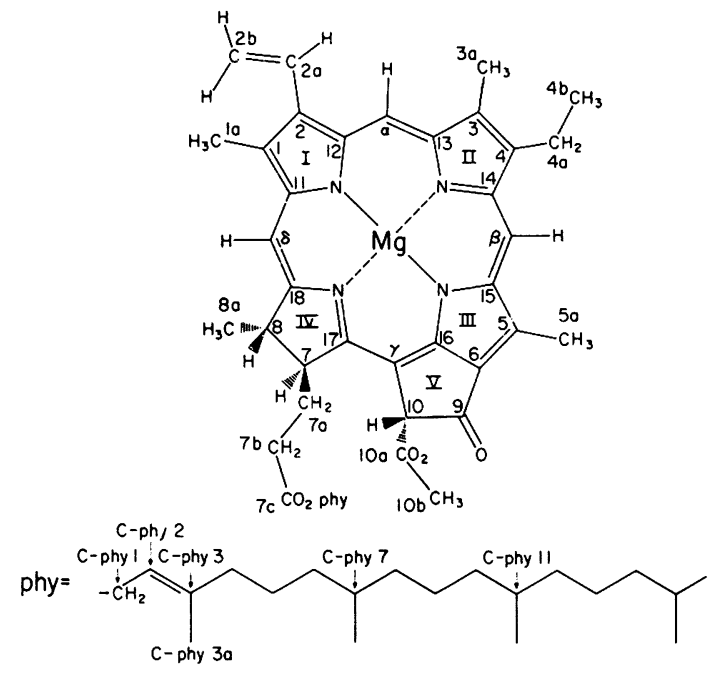

FIGURE 1. Structure and numbering system for chlorophyll. Chlorophyll $b$ has - CHO at position 3. Bacteriochlorophyll has an acetyl function in place of vinyl at position 2 , and an additional $2 \mathrm{H}$ at positions 3 and 4 . Methyl-pheophorbide has $2 \mathrm{H}$ in place of $\mathrm{Mg}$, and $\mathrm{CH}_{3}$ - instead of phytyl at position $7 \mathrm{c}$. Methyl pyrochlorophyllide has a methyl group instead of phytyl, and $2 \mathrm{H}$ at position 10 .

gations agree that the coordination properties of the central $\mathrm{Mg}$ atom are not satisfactorily described by such a formulation. Regardless of the exact way in which $\mathrm{Mg}$ is coordinated to the pyrrole nitrogens, the $\mathrm{Mg}$ atom is coordinatively unsaturated unless an electron donor group is present in one or both of the $\mathrm{Mg}$ axial positions. 22

Not only does the chlorophyll molecule have an acceptor center, it contains a donor center as well. The keto carbonyl function at carbon 9 in ring $\mathrm{V}$ can act as donor in very much the same way that keto $\mathrm{C}=\mathrm{O}$ functions generally do in ordinary ketones. That the $\mathrm{C}-9$ keto $\mathrm{C}=\mathrm{O}$ in chlorophyll can act as donor has received direct confirmation from ${ }^{13} \mathrm{Cmr}$ studies. ${ }^{16}$ The operation of electron donor-acceptor forces thus results in the formation of a number of well-defined chlorophyll species in the laboratory.

\section{Chlorophyll a}

When chlorophyll $a(\mathrm{Chl} a)$ is dissolved in a polar (Lewis base) solvent such as tetrahydrofuran, diethyl ether, acetone, pyridine, or the like, the coordination unsaturation of the central magnesium is alleviated by electron donation by a solvent molecule(s), generating a series of monomer chlorophyll mono- or disolutes, $\mathrm{Chl} \cdot \mathrm{L}_{1}$ or $\mathrm{Chl} \cdot \mathrm{L}_{2}$. At this time, it appears that the central $\mathrm{Mg}$ atom generally assumes a coordination number of five (one $\mathrm{Mg}$ axial position filled) and that a $\mathrm{Mg}$ coordination number of six becomes important only under forcing conditions (such as dissolution in a pure solvent). These monomeric chlorophyll species are intensely fluorescent and, in terms of their $\lambda_{\max }$ in the red, are short wavelength forms (TABLE 1). 
TABLE 1

SPECTROSCOPIC PROPERTIES OF VARIOUS CHLOROPHYLL $a$ SPECIES

\begin{tabular}{|c|c|c|c|}
\hline Species & Solvent & $\begin{array}{c}\lambda_{\max } \\
(\mathrm{nm})\end{array}$ & $\begin{array}{c}\Delta \mathrm{H}^{*} \\
\text { (gauss) }\end{array}$ \\
\hline $\mathrm{Chl}_{2}$ & $\mathrm{CCl}_{4}$ & 662,678 & $9.0 \pm .5$ \\
\hline $\mathrm{Chl}_{2}$ & Benzene & 662,678 & $9.0 \pm .5$ \\
\hline$\left(\mathrm{Chl}_{2}\right)_{\mathrm{n}}$ & $n$-octane & 662,678 & $9.0 \pm .5$ \\
\hline$\left(\mathrm{Chl}_{2}\right)_{\mathrm{n}}$ & Film & 662,678 & $10.0 \pm .5$ \\
\hline $\mathrm{Chl} \cdot \mathrm{CH}_{3} \mathrm{OH}$ & $\mathrm{CH}_{3} \mathrm{OH} / \mathrm{CH}_{2} \mathrm{Cl}_{2}$ & 665 & $9.3 \pm .3 \dagger$ \\
\hline $\mathrm{Chl} \cdot \mathrm{H}_{2} \mathrm{O}$ & $\mathrm{CCl}_{4}$ & 665 & $\sim 9$ \\
\hline $\mathrm{Chl} \cdot \mathrm{THF}$ & THF & 664 & $---\ddagger$ \\
\hline$(\text { Chl } \cdot \text { dioxane })_{n}$ & Decane & $685,695 \mathrm{sh}$ & $9-11 \S$ \\
\hline$\left(\mathrm{Chl}_{2} \cdot \text { pyrazine }\right)_{n}$ & Dodecane & 690 & $9-11 \S$ \\
\hline$(\mathrm{Chl} \text { bipyrimidine })_{\mathrm{n}}$ & Dodecane & 715 & $9-11 \S$ \\
\hline$\left(\mathrm{Chl} \cdot \text { pheophytin } \cdot \mathrm{H}_{2} \mathrm{O}\right)_{n}$ & Dodecane & $715-720$ & $9-11 \S$ \\
\hline$\left(\mathrm{Chl} \cdot \mathrm{H}_{2} \mathrm{O}\right)_{n}$ & Dodecane & 743 & $1-2 \|$ \\
\hline$\left(\mathrm{Chl} \cdot \mathrm{H}_{2} \mathrm{O}\right)_{\mathrm{n}}$ & Film & 743 & $1-2 \|$ \\
\hline
\end{tabular}

\footnotetext{
* The free radicals are produced by chemical oxidation with $\mathrm{I}_{2}$ or $\mathrm{FeCl}_{3}$.

$\dagger$ Line width for $97^{\circ} \mathrm{K}$.

$\ddagger$ THF is an unfavorable solvent of chlorophyll oxidation.

$\S$ The line width depends on oxidant concentration.

II Photo-reversible esr signals are also generated by red light.
}

When $\mathrm{Chl} a$ is dissolved in nonpolar solvents $\left(\mathrm{CCl}_{4}\right.$, benzene, $n$-octane, $n$-dodecane, etc.) that are unable to act as electron donors, the only alternative open to the chlorophyll in the absence of extraneous nucleophiles to satisfy the coordination unsaturation of its central $\mathrm{Mg}$ atom is electron donation from the keto $\mathrm{C}=\mathrm{O}$ group of another chlorophyll molecule. The resulting keto $\mathrm{C}=\mathrm{O}---$ $\mathrm{Mg}$ interaction produces a dimer, $\mathrm{Chl}_{2}$, in $\mathrm{CCl}_{4}$ or benzene (soft nonpolar solvents). In poor (or hard) nonpolar solvents (aliphatic hydrocarbons) additional keto $\mathrm{C}=\mathrm{O}---\mathrm{Mg}$ interactions are formed between dimers, thus forming oligomers $\left(\mathrm{Chl}_{2}\right)_{\mathrm{n}}$, where for example, $\mathrm{n}>10$, in a $0.1 M \mathrm{Chl} a$ solution in $n$-octane. Both $(\mathrm{Chl} a)_{2}$ and $\left(\mathrm{Chl}_{2}\right)_{\mathrm{n}}$ are moderately red-shifted species and are probably entirely free of fluorescence (TABLE 1). The existence of aggregated chlorophyll $a$ species larger than dimers and held together by keto $\mathrm{C}=\mathrm{O}---\mathrm{Mg}$ interactions is established by infrared and nmr observations, and confirmed by direct molecular weight determinations. ${ }^{19}$

Although chlorophyll interactions with monofunctional nucleophiles yield monomeric chlorophyll species, polynuclear chlorophyll species result from interactions with bifunctional ligands such as dioxane or pyrazine. A ligand with two donor atoms such as dioxane has long been known to produce long wavelength forms of chlorophyll, ${ }^{23}$ and the reason now has become clearer. Bifunctional ligands can cross-link chlorophyll monomers or dimers by coordination to $\mathrm{Mg}$. It has become evident that any process that brings chlorophyl] molecules into close proximity generates long wavelength chlorophyll species. ${ }^{24}$ The extent of the red-shift of the red absorption maximum must be a sensitive function of the geometry of the adduct, i.e., how close the chlorophyll molecules are to each other and, probably even more important, their relative orientations and extent of ring overlap. From TABLE 1, it appears that the red-shift produced in $\mathrm{Chl} a$ by interaction with bifunctional ligands is 
significantly larger than that produced by chlorophyll-chlorophyll interactions in dimers and oligomers.

There appears to be at least one bifunctional ligand that has special significance for the in vivo situation, and that is water, $\mathrm{H}_{2} \mathrm{O}$. Water is a bifunctional ligand for chlorophyll in that it can use its nonbonding oxygen electrons for donation to $\mathrm{Mg}$, and its two hydrogen atoms for hydrogen bonding. When water is introduced into a solution of $\mathrm{Chl} a$ in an aliphatic hydrocarbon solvent, remarkable changes occur in both the infrared (FIGURE 2) and the

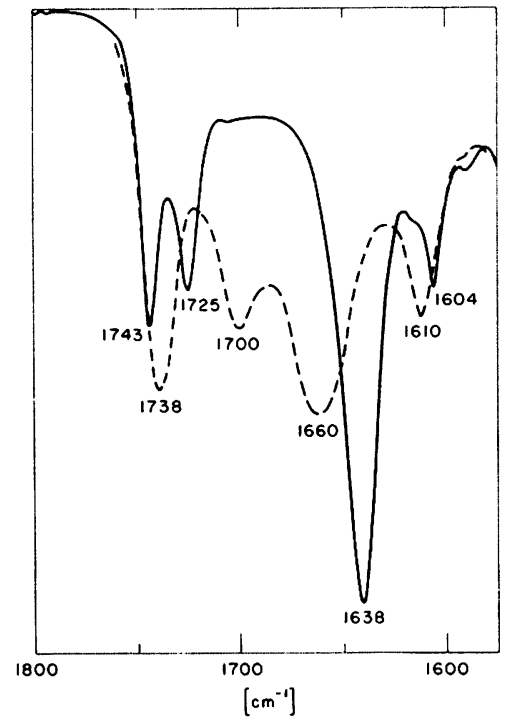

FIGURE 2. Effect of water on the infrared spectrum of chlorophyll oligomer $\left(\mathrm{Chl}_{2}\right)_{\mathrm{n}}$. - - - , $\left(\mathrm{Chl}_{2}\right)_{\mathrm{n}} ;$ phyll-water adduct.

visible absorption spectra. ${ }^{9}$ The solution changes in color from the characteristic blue of chlorophyll oligomers to a yellow-green with $\lambda_{\max } \sim 740 \mathrm{~nm}$. A red-shift (measured from the absorption maximum of $\mathrm{Chl} \cdot \mathrm{H}_{2} \mathrm{O}$ monomer dissolved in benzene) of about $80 \mathrm{~nm}$ thus occurs on formation of the chlorophyll-water adduct in an aliphatic hydrocarbon medium. From infrared studies in both the carbonyl and $\mathrm{O}-\mathrm{H}$ stretch regions, ${ }^{10}$ it appears that both carbonyl functions of ring $\mathrm{V}$ are hydrogen-bonded to water coordinated to the $\mathrm{Mg}$ atom of another chlorophyll molecule. The free keto $\mathrm{C}=\mathrm{O}$ absorption seen in the infrared spectra of both $\left(\mathrm{Chl}_{2}\right)$ and $\left(\mathrm{Chl}_{2}\right)_{n}$ is almost completely absent in the chlorophyll-water adduct, and the ester $\mathrm{C}=\mathrm{O}$ absorption maxima are split, indicative of nonequivalence of the ester $\mathrm{C}=\mathrm{O}$ functions in the propionic acid ester at position 7 and the carbomethoxy $\mathrm{C}=\mathrm{O}$ group of ring $\mathrm{V}$. Consequently, the basic unit of the chlorophyll-water adduct is formulated ${ }^{10}$

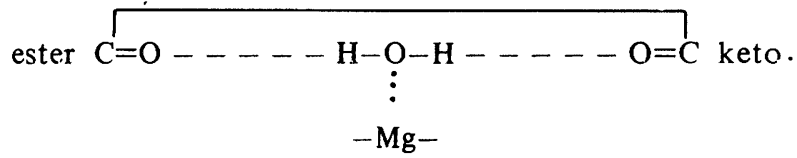


Whereas the $\left(\mathrm{Chl}_{2}\right)_{n}$ oligomer in an aliphatic hydrocarbon solvent sediments only slowly in the ultracentrifuge, the chlorophyll-water adduct can be sedimented in a few minutes at $\times 50000 \mathrm{~g}$, showing that the chlorophyll-water adduct is an entity of colloidal dimensions. An examination of the basic unit suggested for the chlorophyll-water adduct indicates that the interaction can be repeated to form a micelle of colloidal dimensions, in which chlorophyll molecules are arranged in a staggered configuration with a water molecule intercalated between parallel but laterally displaced chlorophyll molecules. Unlike $\left(\mathrm{Chl}_{2}\right)_{n}$, which shows no x-ray diffraction pattern, the chlorophyll-water adduct shows a $7.5 \AA$ periodicity that can be assigned to a $\mathrm{Mg}-\mathrm{Mg}$ periodicity in parallel chlorophyll molecules separated by $\mathrm{H}_{2} \mathrm{O} .{ }^{10}$ Direct analysis by v.p. chromatography shows a chl : water ratio in the adduct of $1: 1$. We, therefore, have assigned the structure $\left(\mathrm{Chl} \cdot \mathrm{H}_{2} \mathrm{O}\right)_{\mathrm{n}}$ to the chlorophyll-water adduct. 17

This $\left(\mathrm{Chl} \cdot \mathrm{H}_{2} \mathrm{O}\right)_{n}$ adduct is of critical importance to a consideration of the light conversion step in photosynthetic organisms. Although the $\left(\mathrm{Chl} \cdot \mathrm{H}_{2} \mathrm{O}\right)_{n}$ species does not appear to be a naturally occurring component of green plants, entities with similar structures may occur naturally in photosynthetic bacteria (see below). Moreover, of all the chlorophyll species so far prepared in the laboratory, the $\left(\mathrm{Chl} \cdot \mathrm{H}_{2} \mathrm{O}\right)_{n}$ adduct is the only one from which a reversible photo-esr signal can be elicited by irradiation with red light. ${ }^{17}$ This signal is extraordinarily narrow (TABLE 1) and the line width is best interpreted to result from a process of rapid spin migration that effectively delocalizes the unpaired spin over the entire micelle. (Details of the delocalization process, and a quantitative analysis of the effect of spin delocalization on line width are given below.)

The origin of charge separation in a $\left(\mathrm{Chl} \mathrm{H} \mathrm{H}_{2} \mathrm{O} \mathrm{Chl}\right)$ unit can be formulated in terms of hydrogen abstraction from water by keto $\mathrm{C}=\mathrm{O}$, a highly respectable and widely recognized photochemical process. 25,26 Ketone abstraction of hydrogen photochemically ordinarily requires light in the $3500-4500 \AA$ region. It should be recognized, however, that the water molecule coordinated to the central $\mathrm{Mg}$ atom of chlorophyll in the $\left(\mathrm{Chl} \mathrm{H}_{2} \mathrm{O} \mathrm{Chl}\right)$ unit can by no means be equated in structure with bulk water. ${ }^{17}$ It is well-known that addition of metal cations to water and alcohols significantly increases the acidity of the species coordinated to the cation. ${ }^{27}$ Thus, the addition of $1 M \mathrm{NaClO}_{4}$ to pure methanol raises the $\mathrm{pK}_{\mathrm{a}}$ of $\mathrm{CH}_{3} \mathrm{OH}$ from 17 to 14 , a thousand-fold increase in acidity. ${ }^{28} \mathrm{In}$ the $\left(\mathrm{Chl} \mathrm{H}_{2} \mathrm{O} \mathrm{Chl}\right)$ sandwich, the water protons are thus expected to be significantly more acidic than bulk water, an expectation confirmed by proton magnetic resonance spectroscopy. ${ }^{17}$ The unusual strength of the hydrogen bonds formed by $\mathrm{Mg}$-coordinated water can in this view be considered a direct consequence of the enhanced acidity of the coordinated water molecule. Further, hydrogen abstraction from water in the $\left(\mathrm{Chl} \mathrm{H}_{2} \mathrm{O} \mathrm{Chl}\right)$ unit is by no means equivalent energetically to the photolysis of water $\mathrm{H}_{2} \mathrm{O} \rightarrow \cdot \mathbf{H}+\cdot \mathrm{OH}$. An $\mathrm{O}-\mathrm{H}$ bond is broken in water by $\mathrm{H} \cdot$ removal, but a new $\mathrm{O}-\mathrm{H}$ forms from the keto $\mathrm{C}=\mathrm{O}$ group; the energy requirement must thus be significantly less than that required for bond rupture in pure water. The altered state of $\mathrm{Mg}$-coordinated water, and the generally lower energy requirement to be expected for hydrogen abstraction (either as $\mathrm{H}^{\cdot}$ or $\mathrm{H}^{+}$) in a $\left(\mathrm{Chl} \mathrm{H}_{2} \mathrm{O} \mathrm{Chl}\right)$ structure thus are compatible with the laboratory observation that the energy of red light quanta $(>650 \mathrm{~nm})$ is adequate for charge separation in the $\left(\mathrm{Chl} \cdot \mathrm{H}_{2} \mathrm{O}\right)_{\mathrm{n}}$. 


\section{ANTENNA CHLOROPHYLL}

We have advanced the hypothesis elsewhere, $29-31$ that antenna chlorophyll in green plants has a structure very similar to that of chlorophyll oligomer, $\left(\mathrm{Chl}_{2}\right)_{\mathrm{n}}$. This conclusion is based mainly on electronic transition spectroscopy. 21 Bulk or antenna chlorophyll in the plant has its absorption maximum in the red near $680 \mathrm{~nm}$. Computer deconvolution of the visible absorption spectra of in situ antenna chlorophyll and chlorophyll oligomers in nonpolar solvents show a high degree of similarity between gaussian components of the two red envelopes. Over the entire concentration range $10^{-6} \mathrm{M}$ to $10^{-1} \mathrm{M}$, the red band of chlorophyll $a$ solutions in aliphatic hydrocarbon solvents can be deconvoluted into gaussian components at $628,650,662,678$, and $703 \mathrm{~nm}$. The most important change that is observed with increasing concentrations, i.e., increase in size of the oligomer, is a change in the relative areas of the 662 and $678 \mathrm{~nm}$ components, with the area of the latter increasing at the expense of the former as the oligomer becomes larger. In large oligomers, such as are present in a $0.1 M$ solution of $\mathrm{Chl} a$ in $n$-octane, the $662 \mathrm{~nm}$ component is vestigial, and the red gaussian component at $678 \mathrm{~nm}$ constitutes most of the red envelope. In a general way, we associate the areas of the 662 and $678 \mathrm{~nm}$ gaussians with configuration populations, that is, they indicate the relative sizes of populations in which two chlorophyll molecules are arranged vis à vis each other. We associate the $662 \mathrm{~nm}$ gaussian with an orthogonal configuration of two chlorophylls bound by the coordination interaction keto $\mathrm{C}=\mathrm{O}---\mathrm{Mg}$, and the $678 \mathrm{~nm}$ gaussian with the two chlorophylls in a parallel orientation. Thus, the studies on laboratory systems lead to a rather surprising conclusion: the wavelength of the absorption maximum of the $\left(\mathrm{Chl}_{2}\right)_{n}$ oligomer species, or even the maxima of the gaussian components, are not at all a sensitive function of the size of the aggregate. Both chlorophyll $a$ dimer and $\left(\mathrm{Chl}_{2}\right)_{>10}$ have their maximum absorption in the red near $680 \mathrm{~nm}$. The intuitive conclusion that the larger the aggregate the greater its red shift is thus contrary to experiment.

An examination of the visible absorption spectrum of algae (intact organisms or sonicates, or active center preparations) by the same deconvolution techniques demonstrates that the in situ red envelope can be fitted by gaussians very similar in wavelength and half-band width to those required for concentrated $\mathrm{Chl} a$ solutions in aliphatic hydrocarbon solvents. In the in situ spectra, the blue gaussian at $662 \mathrm{~nm}$ is even smaller and the red gaussian at $678 \mathrm{~nm}$ larger than those in concentrated $\mathrm{Chl} a$ solutions in $n$-octane. We take the great similarity between the deconvoluted red bands of antenna chlorophyll in the plant and that of a concentrated $\mathrm{Chl} a$ solution in aliphatic hydrocarbon solvents, established by direct molecular weight measurements to contain chlorophyll $a$ oligomers with molecular weights greater than 20,000 , to provide a reasonable basis for the identification of in vivo antenna chlorophyll in green plants with $\left(\mathrm{Chl}_{2}\right)_{n}$ oligomers.

The subject of antenna chlorophyll in photosynthetic bacteria is more complex and cannot be entered into fully here. We merely note that the high concentration of P-865 in living bacteria, and the fact that only a small fraction of the P-865 present seems to be photoreactive blurs the distinction between photoreactive and antenna chlorophyll in these organisms. The $865 \mathrm{~nm}$ absorbing species of bacteriochlorophyll is a $\mathrm{BChl}-\mathrm{H}_{2} \mathrm{O}$ adduct ${ }^{29}$ and a major cellular component, whereas in the green plants $\mathrm{P}-700\left(\mathrm{Chl} \mathrm{H}_{2} \mathrm{O} \mathrm{Chl}\right)$ entities are present only in low concentrations. What makes some P-865 an active center in photosynthetic bacteria may therefore depend on the subsequent availability of 
a secondary electron acceptor rather than a particular structural characteristic. We intend to enter into these matters in more detail elsewhere.

\section{PHOTOREACTIVE CHLOROPH:LL}

Almost two decades after the pioneering discovery of Commoner, Heise, and Townsend ${ }^{32}$ electron spin resonance and electron nuclear double resonance have become the most revealing spectroscopic techniques that so far have been brought to bear on the nature of photoreactive chlorophyll in photosynthetic organisms.

Irradiation of intact photosynthetic plants with red light produces relatively intense gaussian esr signals of line widths ranging from about 7 to 10 gauss, with a g-value very near to that of the free electron. ${ }^{33,34}$ Currently, it is generally believed that this esr signal originates in $\mathrm{Chl}^{+}$cation free radicals formed in the primary act of photosynthesis. These free radical signals are associated with the oxidation of the so-called photoreaction center chlorophyll pigments, i.e., P-700 in green, oxygen-evolving organisms, and P-865 in certain purple photosynthetic bacteria. An explanation of the nature of this free radical signal first detected in 1956 by Commoner and coworkers ${ }^{32}$ has been an enormous task and only recently by the application of esr and endor spectroscopy, in conjunction with infrared and nuclear magnetic resonance spectroscopy, have any specific details about photoreactive chlorophyll been understood. Previously we proposed that this chlorophyll free radical signal originates in a special pair of chlorophyll molecules on the basis of esr studies. ${ }^{35}$ The conclusions derived from esr studies were recently confirmed by preliminary endor results. ${ }^{18,36}$ These endor and esr studies provide a detailed description of the nature of the primary free radical formed in the light conversion step of photosynthesis and provide very strong evidence for the validity of our special pair model for photoreactive chlorophyll.

Endor, a spectroscopic technique first invented by Feher, ${ }^{37}$ is rapidly becoming an indispensible extension of esr. At present, it provides the best probe for the study of chlorophyll free radicals. The value of endor arises from the greatly increased resolution that it affords, which is not obtainable by application of ordinary esr. In conjunction with chlorophylls of unusual isotopic composition we can now map the location of the unpaired electron in chlorophyll free radicals both in vitro and in vivo with considerable precision. It is important to note that endor and esr can be applied directly to intact photosynthetic organisms without encountering interfering signals. Thus, in the application of these techniques it is not necessary or even desirable to employ reaction center preparations.

A typical endor spectrum of in vivo bacteriochlorophyll and in vitro bacteriochlorophyll is shown in FIGURE 3. The in vivo spectrum is obtained on the esr signal generated chemically with $\mathrm{K}_{3} \mathrm{Fe}(\mathrm{CN})_{6}$ from whole cells of $R$. rubrum. The chemically induced signal is believed identical to the light-induced esr signal since all measurable parameters are essentially the same. ${ }^{33}$ The in vitro spectrum is obtained by chemical oxidation (with iodine, $\mathrm{I}_{2}$, or ferric chloride, $\mathrm{FeCl}_{3}$ ) of monomeric bacteriochlorophyll dissolved in $\mathrm{CH}_{2} \mathrm{Cl}_{2}-\mathrm{MeOH}$ solution. The in vivo endor spectrum is very different from the in vitro spectrum known to originate from monomeric bacteriochlorophyll free radical cations. The differences in the endor spectra were of course to be expected since the in vivo esr signal is a single gaussian envelope of $\sim 9$ gauss line width, whereas the in vitro esr signal is a single gaussian envelope of $\sim 13$ gauss line width. The in vivo 


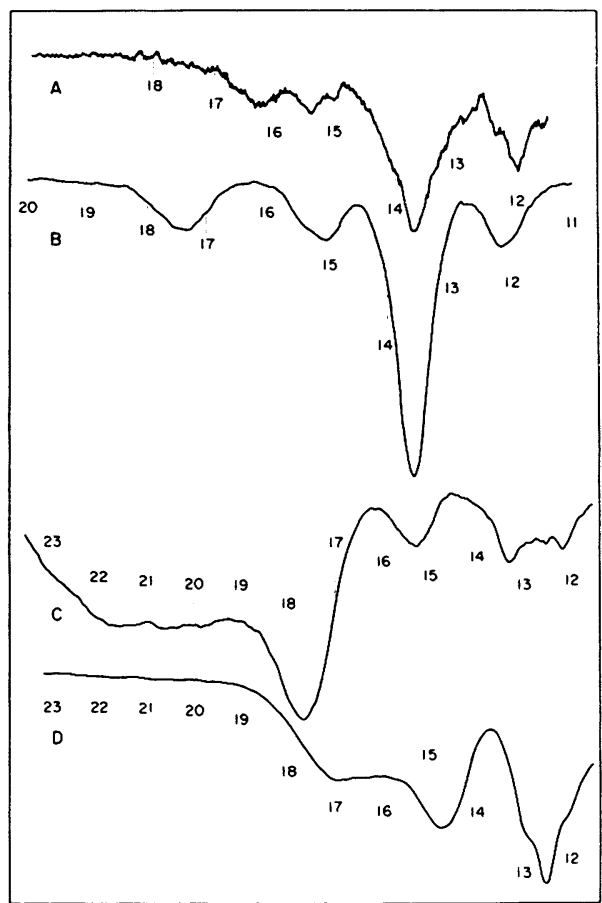

FIGURE 3. Comparison of in vivo and in vitro chlorophyll endor. (A) In vivo green algae (C. vulgaris) oxidized by $\mathrm{KFe}(\mathrm{CN})_{6}, \Delta \mathrm{H}=7.2 \mathrm{~g}, 97^{\circ} \mathrm{K}$. (B) In vitro chlorophyll $a$ oxidized by $\mathrm{I}_{2}$ or $\mathrm{FeCl}_{3}$ in $\mathrm{C}^{1} \mathrm{H}_{3} \mathrm{O}^{1} \mathrm{H}: \mathrm{C}^{1} \mathrm{H}_{2} \mathrm{Cl}_{2} 1: 3(\mathrm{v} / \mathrm{v}), \Delta \mathrm{H}=9.3 \mathrm{~g}, 97^{\circ} \mathrm{K}$. (C) In vitro bacteriochlorophyll oxidized by $\mathrm{I}_{2}$ or $\mathrm{FeCl}_{3}$ in $\mathrm{C}^{2} \mathrm{H}_{3} \mathrm{O}^{2} \mathrm{H}: \mathrm{C}^{2} \mathrm{H}_{2} \mathrm{Cl}_{2}, 1: 3(\mathrm{v} / \mathrm{v}), \Delta \mathrm{H}=13 \mathrm{~g}$, $\simeq 15^{\circ} \mathrm{K}$. (D) In vivo photosynthetic purple bacteria $\left(R\right.$. rubrum) oxidized by $\mathrm{K}_{3} \mathrm{Fe}(\mathrm{CN})_{6}$, $\Delta \mathrm{H}=9 \mathrm{~g}, \simeq 15^{\circ} \mathrm{K}$.

line width is approximately $40 \%$ narrower than the corresponding in vitro signal. The large discrepancy between the in vivo and in vitro esr and endor spectral features demands explanation because both signals originate from bacteriochlorophyll. Furthermore, an entirely comparable situation exists in chlorophyll $a$ systems as shown in FIGURE 3. Again the esr line width of the in vivo chlorophyll ( 7.2 gauss) is approximately $40 \%$ narrower than that of in vitro monomeric chlorophyll (9.3 gauss), and again the endor spectra are quite different as well.

Our previous in vitro chlorophyll esr studies provide an experimental basis for establishing the significance of such esr line width changes. Monomers, dimers, and anhydrous oligomers of $\mathrm{Chl} a$ all give an esr signal with $\sim 9.5$ gauss linewidth (TABLE 1). None of these species are photoreactive, and all of them require chemical oxidation to produce an esr signal. On the other hand, the highly red-shifted $\mathrm{Chl} a-\mathrm{H}_{2} \mathrm{O}$ adduct, $\left(\mathrm{Chl} \cdot \mathrm{H}_{2} \mathrm{O}\right)_{n}$, gives an unusually narrow, reversible photoreactive signal 1 to 2 gauss in line width. As far as we know this is the only species of chlorophyll that produces photo-reversible chlorophyll free radicals by irradiation with red light. This red-shifted $743 \mathrm{~nm}$ chlorophyll-water adduct is 
known to be highly aggregated and to be of colloidal dimensions. 9 The very narrow esr signal observed in this adduct suggests that efficient unpaired spin delocalization can occur over many chlorophyll molecules of the micelle, which greatly narrows the esr line widths. The line width of an unpaired spin delocalized over an aggregate of $\mathrm{N}$ chlorophyll molecules is inversely proportional to the square root of the number of molecules participating in spin delocalization: ${ }^{35}$

$$
\Delta \mathrm{H}_{\mathrm{N}}=\Delta \mathrm{H}_{\text {monomer }} / \sqrt{\mathrm{N}}
$$

If the in vivo line width is taken to be $\Delta \mathrm{H}_{\mathrm{N}}$, and the in vitro line width to be $\Delta \mathrm{H}_{\text {monomer }}$, Equation 1 predicts that the narrowing of the in vivo photo-esr signal results from the delocalization of the spin over just two molecules of chlorophyll. This is true for both algae and bacteria. Such a special pair model requires that the equal spin delocalization over $\mathrm{N}$ molecules obeys the following equation, where $\mathrm{A}$ is a hyperfine proton-electron constant:

$$
A_{N}=A_{\text {monomer }} / N
$$

Comparison of the value of the coupling constants in vivo and in vitro in monomer chlorophyll should show a decrease strictly proportional to $1 / \mathrm{N}$, where $\mathrm{N}$ is the number of molecules over which the unpaired spin is delocalized. Although no coupling constants can be extracted from the featureless signals, endor yields these important parameters, and thus provides a stringent test of the special pair model for photoreactive chlorophyll. The observed changes in esr line width suggest that $\mathrm{N}=2$, so that the in vivo coupling constants observed by endor should be one-half the endor coupling constants of monomeric in vitro cation chlorophyll free radicals.

The special pair model for photoreactive chlorophyll explains two important aspects of photoreactive chlorophyll: (1) the large red shift to $700 \mathrm{~nm}$ or $865 \mathrm{~nm}$; and (2) the narrowing of the in situ esr signal. The validity of the special pair model can be tested most directly by application of endor. The endor spectra of FIGURE 3 are much more complicated than the simple esr or optical spectra obtained on the same system; thus endor spectra provide a more detailed "fingerprint" of chlorophyll free radicals than any other method provides, and one which has in vivo application. The special pair model should be able to explain the large differences in the endor spectra of in vitro and in vivo chlorophyll.

For the special pair model to be confirmed by endor, we require "maps" of the unpaired electron distribution, which are compatible with a distribution of the unpaired electron over one chlorophyll molecule in vitro and over two chlorophyll molecules in vivo. These electron "maps" are accessible only through a full interpretation or assignment of all the endor transitions observed in the spectra. Once an assignment has been made of a particular spectral line to a particular functional group, $\mathrm{R}_{\mathbf{i}}$, within the chlorophyll molecule, we can readily calculate the unpaired spin density, $\rho_{\mathrm{i}}$, at the $\mathrm{i}^{\text {th }}$ site by a McConnell type relation:

$$
\rho_{\mathrm{i}}=\mathrm{Q} / \mathrm{A}_{\mathrm{i}}
$$

where $Q$ is a well known constant established by numerous experimental and theoretical studies, ${ }^{38}$ and $A_{i}$ is the hyperfine coupling constant that is observed by endor. It is through these spin density determinations at specific sites within the chlorophyll molecular formula that we can map the location of the unpaired 
electron. Thus, we require assignments of endor transitions to a particular group of nuclei within the chlorophyll molecule.

At present, assignments can be established only by changing the isotopic composition of the hydrogen atoms of the chlorophyll from ${ }^{1} \mathrm{H}$ to ${ }^{2} \mathrm{H}$ in positions in the chlorophyll molecule. Such studies are difficult to carry out in vitro and are clearly limited in vivo. However, through a combination of studies on isotopically altered chlorophylls both in vivo and in vitro we have been able to provide a reasonably detailed map of the unpaired electron both in vitro and in vivo sufficient for a test of the special pair model. These spin maps show that in vivo the unpaired electron is essentially equally distributed over two chlorophyll molecules, thus confirming the validity of the special pair model.

The endor spectra of FIGURE 3 represent transitions associated with only those protons that are coupled to the unpaired electron. Ideally, in order to assign these transitions it would be necessary to prepare both in vivo and in vitro ${ }^{2} \mathrm{H}-{ }^{1} \mathrm{H}$-chlorophylls in which each hydrogen position in the molecule, one at a time, has been completely exchanged with ${ }^{1} \mathrm{H}$ hydrogen (or vice versa), and then to record the endor spectrum. Comparison of the endor spectrum before and after the isotopic exchange will then establish the role of protons at the exchanged site in generating the endor spectrum. By exchanging one site at a time it is possible therefore to map unambiguously the location of the unpaired electron in vivo and in vitro over the entire chlorophyll molecule.

In practice, however, such isotope permutation experiments can be carried out in vivo only by biosynthesis, where only a relatively few possibilities of isotopic substitution exist. Of course, any alteration in isotopic composition that can be accomplished biosynthetically provides a source of chlorophyll of unusually isotopic composition that can be used for further in vitro modifications. Furthermore, and perhaps more important, this procedure provides the only direct experimental link between assignments in vitro and in vivo.

The possible isotope exchange experiments on chlorophyll in vitro that can be carried out are more numerous, but are still limited because the experimental conditions required to effect hydrogen exchange may also cause chemical changes in the structure of the chlorophyll. We have consequently applied exchange methods in chlorophyll derivatives that have the required chemical stability, but do not necessarily exist in nature. The basic requirement for our purpose is that the esr and endor spectra of the chlorophyll-like compound yield spectra essentially identical to the endor spectrum of chlorophyll itself. This requirement immediately eliminates from use such favorite laboratory substances as zinc octaethyl porphyrin and magnesium tetraphenyl porphyrin. The model compound of choice in our work was methyl pyrochlorophyllide $a .{ }^{39}$ This is a derivative of chlorophyll $a$ in which the phytyl group is replaced by methyl and the carbomethoxy group at position 10 (FIGURE 1) is replaced by ${ }^{1} \mathrm{H}$. The cation radical of this compound gives an endor signal sufficiently similar to that of the chlorophyll $a$ radical to justify fully its use, as is shown in FIGURE 4. In FIGURE 4 we also define our coupling constant nomenclature for chlorophyll $a$ systems. Bacteriochlorophyll systems use the same assignment system except that $A_{2}$ is not expected to be (and has not in fact been) observed.

We have in addition prepared a number of isotopically permuted derivatives of methyl pyrochlorophyllide $a$ to assist in the elucidation of the in vitro coupling constants of chlorophyll $a$. As one example of these experiments we show (FIGURE 4) the endor spectra of methyl pyrochlorophyllide $a$, in which the $-\mathrm{CH}_{3}$ group at position 5 and the two protons at position 10 have been exchanged with ${ }^{2} \mathrm{H}$. Comparison of the $-\mathrm{CH}_{3}$ and $-\mathrm{C}^{2} \mathrm{H}_{3}$ spectra shows that 


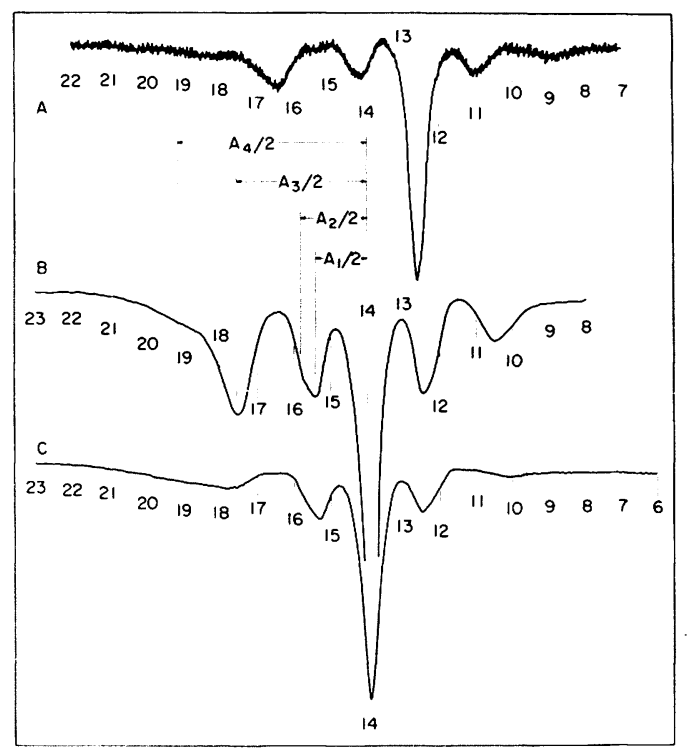

FIGURE 4. Comparison of endor spectra of chlorophyll $a$ and methylpyrochlorophyllide $a$, oxidized by $\mathrm{I}_{2}$ in $\mathrm{C}^{1} \mathrm{H}_{3} \mathrm{O}^{1} \mathrm{H}: \mathrm{C}^{1} \mathrm{H}_{2} \mathrm{Cl}_{2}, 1: 3(\mathrm{v} / \mathrm{v})$. (A) Chlorophyll $a$. (B) Me thyl-pyrochlorophyllide $a$. The four larger coupling constants are indicated. $\mathrm{A}_{0}$ is not sliown since this very small coupling constant is obscured by the intense solvent proton peak near $14 \mathrm{MHz}$. (C) Methyl-pyrochlorophyllide $a$ with $\sim 90 \%{ }^{2} \mathrm{H}$ at position 5.

the peaks at 17.6 and $10.5 \mathrm{MHz}$ have essentially disappeared in the (partially) deuterated ${ }^{2} \mathrm{H}$-methyl pyrochlorophyllide system. Since the endor spectrum appears the same as that for methyl pyrochlorophyllide $a$ when only the protons at position 10 are deuterated with ${ }^{2} \mathrm{H}$, we know that the 5 -methyl group of ring III is the origin of the $7.22\left(\mathrm{~A}_{3}\right)$ coupling constant in methyl pyrochlorophyllide $a$, and that same assignment can be made for the corresponding peaks observed in Chl $a$ endor spectra. The results of many such isotope substitution endor experiments are summarized in TABLE 2.

Combining our results with the theoretical calculations of Felton and coworkers, 40,41 we are now in a position to assign most of the proton coupling constants in chlorophyll free radicals. First, however, let us discuss some supporting bacteriochlorophyll results. When the purple photosynthetic bacterium $R$. rubrum is grown in ${ }^{2} \mathrm{H}_{2} \mathrm{O}$ on the organic substrate ${ }^{1} \mathrm{H}$ succinic acid, the bacteriochlorophyll (both in vivo and in vitro) contains ${ }^{1} \mathrm{H}$ (in endor-active positions) only on methyl groups. ${ }^{42}$ Comparison of FIGURES 3 and 5 shows that only the two intense resonances remain (i.e., 4 peaks) even though only methyl groups contain protons. Thus, these two peaks must arise from the 1and 5-methyl groups, in excellent agreement with the assignments previously established for $\mathrm{Chl} a$.

${ }^{2} \mathrm{H}$-Bacteriochlorophyll dissoved in methanol was exchanged with $\mathrm{CF}_{3} \mathrm{COOH}$, resulting in $100 \%$ exchange of the $\mathrm{C}-10$ hydrogen, and $\sim 90 \%$ exchange of one methine proton, a $\sim 65 \%$ exchange of another methine proton, and $\sim 20 \%$ 
TABLE 2

ENDOR COUPLING CONSTANTS IN MHz

\begin{tabular}{lccccc}
\hline \hline & $\mathrm{A}_{0}{ }^{*}$ & $\mathrm{~A}_{1}$ & $\mathrm{~A}_{2}$ & $\mathrm{~A}_{3}$ & $\mathrm{~A}_{4}$ \\
Chlorophyll $a$ & .67 & 3.19 & 3.72 & 7.42 & $\sim 11.8$ \\
\hline Methyl-pyrochlorophyllide $a$ & & & & & \\
Normal isotopic comp. & .81 & 3.02 & 3.81 & 7.22 & $\sim 10.9$ \\
5-CD $10 \mathrm{CD}_{2}$ & $\dagger$ & 2.83 & 3.50 & v. weak & $7-10$ \\
$10 \mathrm{CD}_{2}$ & .67 & 2.88 & 3.47 & 7.54 & $\sim 9.5$ \\
\hline
\end{tabular}

* $A_{0}$ is such a small coupling constant that it is only measurable in ${ }^{2} \mathrm{H}$ solvents. In FIGURE 4(B) $A_{0}$ is not shown since it is obscured by the intense matrix signal of the ${ }^{1} \mathrm{H}$ solvent.

$\left\lceil{ }^{1} \mathrm{H}\right.$ solvents used on this sample such that $A_{0}$ is not measurable. See FIGURE 3(C) for a typical endor spectrum that shows the smallest coupling constant, $A_{0}$, when using $2 \mathrm{H}$ solvents.

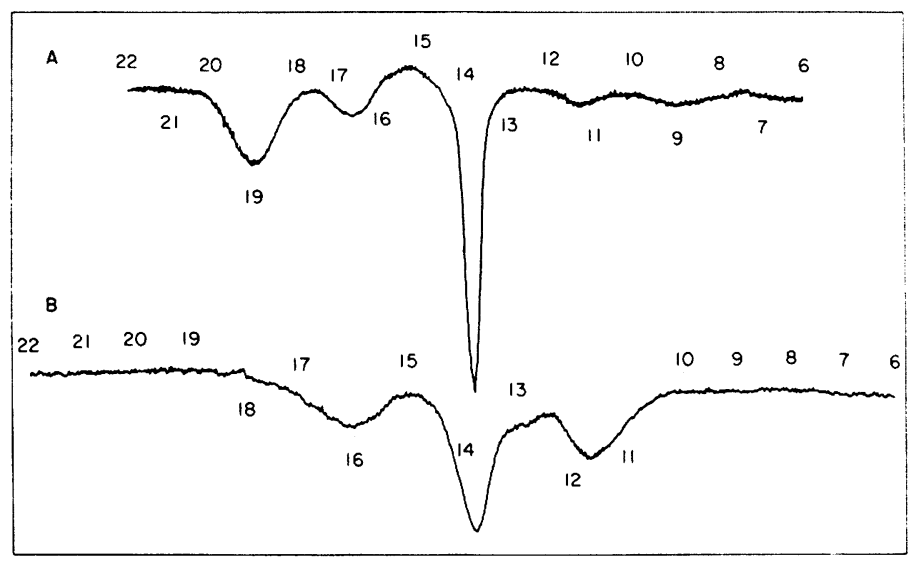

FIGURE 5. Comparison of in vivo and in vitro endor spectra of $2 \mathrm{H}$-bacteriochlorophyll containing ${ }^{1} \mathrm{H}$ at endor-active positions 1 and 5 only. The bacteria from which this bacteriochlorophyll was isolated were grown in ${ }^{2} \mathrm{H}_{2} \mathrm{O}$ on ${ }^{1} \mathrm{H}$ succinic acid. (A) In vitro bacteriochlorophyll oxidized by $\mathrm{I}_{2}$ in $\mathrm{C}^{1} \mathrm{H}_{3} \mathrm{O}^{1} \mathrm{H}: \mathrm{C}^{1} \mathrm{H}_{2} \mathrm{Cl}_{2}, 1: 3(\mathrm{v} / \mathrm{v}), \sim 97^{\circ} \mathrm{K}$. (B) In vivo photosynthetic bacteria $\left(R\right.$. rubrum) oxidized by $\mathrm{K}_{3} \mathrm{Fe}(\mathrm{CN})_{6}, \sim 97^{\circ} \mathrm{K}$.

exchange of the methyl groups at positions $1,2 \mathrm{~b}$ and 5 . The extent of exchange is readily established by proton magnetic resonance spectroscopy. Two endor spectra of the exchanged bacteriochlorophyll are shown in FIGURE 6. Spectrum (A) is recorded at normal gain and reveals resonance near the free proton frequency of $14.2 \mathrm{MHz}$. Spectrum (B) is recorded at ten times normal gain and in such a manner as to emphasize resonances near 17 and $19 \mathrm{MHz}$. These latter two peaks are present in spectrum (A) but are obscured by noise. Since we have already assigned the peaks near 17 and $19 \mathrm{MHz}$ to the 1- and 5-methyl groups which have been partially exchanged by the $\mathrm{CF}_{3} \mathrm{COOH}$, we know the smaller proton coupling constants, $A_{0}$, observed in spectrum (A) must be due to the exchanged methines and/or the $\mathrm{C}-10$ proton. 


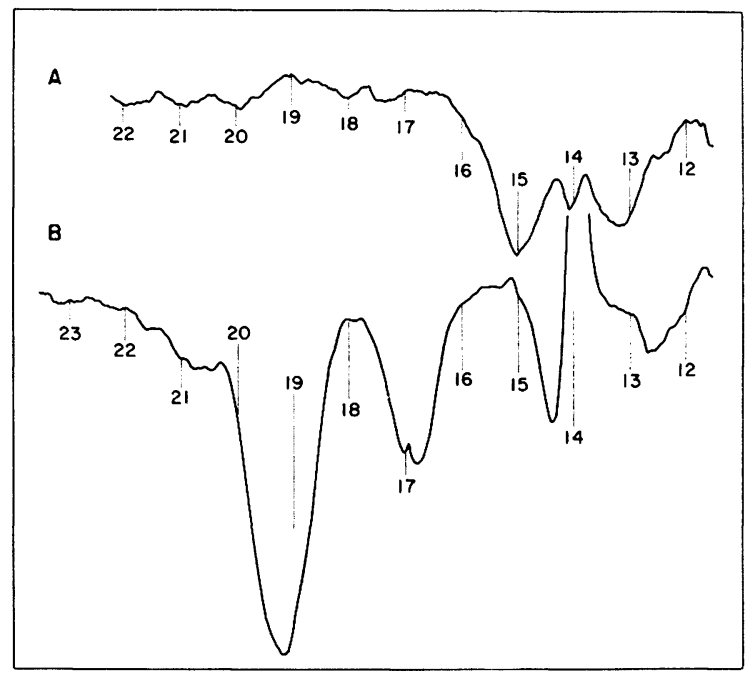

FIGURE 6. Endor spectra of ${ }^{1} \mathrm{H}^{+}$exchanged ${ }^{2} \mathrm{H}$-bacteriochlorophyll. Oxidized by $\mathrm{I}_{2}$ in $\mathrm{C}^{2} \mathrm{H}_{3} \mathrm{O}^{2} \mathrm{H}: \mathrm{C}^{2} \mathrm{H}_{2} \mathrm{Cl}_{2}, 1: 3(\mathrm{v} / \mathrm{v})$. (A) Normal gain. (B) Ten times normal gain.

Combining all the foregoing observations we have summarized all our results and assignments for in vitro chlorophyll $a$ and bacteriochlorophyll in TABLE 3 . This table provides the basis for interpreting in vivo spectra recorded on photosynthetic organisms. It is immediately apparent that it is not possible to interpret the in vivo endor spectra without invoking the concept of our special pair model. The special pair model permits the in vivo endor spectra to be interpreted with the same set of coupling constants shown in TABLE 3, except that the value of each in vivo coupling constant is approximately one-half of the

TABLE 3

ASSIGNMENT OF ENDOR PROTON-ELECTRON COUPLING CONSTANTS FOR in Vitro CHLOROPHYLL

\begin{tabular}{|c|c|c|c|c|c|c|}
\hline & & $A_{0}$ & $\mathbf{A}_{1}$ & $\mathrm{~A}_{2}$ & $A_{3}$ & $\mathrm{~A}_{4}$ \\
\hline \multirow[b]{2}{*}{$\mathrm{Chl} a$} & $\begin{array}{l}\text { Magnitude } \\
(\mathrm{MHz})\end{array}$ & .67 & 3.19 & 3.72 & 7.42 & 11.8 \\
\hline & Assignment & $\begin{array}{c}\alpha-\mathrm{H} \\
\beta-\mathrm{H} \\
10-\mathrm{H}\end{array}$ & \multicolumn{2}{|c|}{$\begin{array}{l}1 \mathrm{a}-\mathrm{CH}_{3} \\
3 \mathrm{a}-\mathrm{CH}_{3} \\
4 \mathrm{a}-\mathrm{CH}_{2}\end{array}$} & $5 \mathrm{a}-\mathrm{CH}_{3}$ & $\begin{array}{l}7-\mathrm{H} \\
8-\mathrm{H}\end{array}$ \\
\hline \multirow{2}{*}{ BChl } & $\begin{array}{l}\text { Magnitude } \\
(\mathrm{MHz})\end{array}$ & 1.4 & 5.32 & --- & 9.8 & $\overline{14.0}$ \\
\hline & Assignment & $\begin{array}{c}\alpha-\mathrm{H} \\
\beta-\mathrm{H} \\
\delta-\mathrm{H} \\
10-\mathrm{H}\end{array}$ & $1 \mathrm{a}-\mathrm{CH}_{3}$ & --- & $5 \mathrm{a}-\mathrm{CH}_{3}$ & $\begin{array}{l}3-\mathrm{H} \\
4-\mathrm{H} \\
7-\mathrm{H} \\
8-\mathrm{H}\end{array}$ \\
\hline
\end{tabular}


corresponding in vitro value (TABLES 4 and 5). This halving of coupling constants in vivo is required by the special pair model, and the endor data thus provide excellent confirmation of the special pair model.

This interpretation of in vivo data on the basis of in vitro coupling constants and the special pair model can be further supported if we are able to assign in vivo endor coupling constants in a completely independent manner. In the case of $R$. rubrum, we can accomplish this by growing the organism in ${ }^{2} \mathrm{H}_{2} \mathrm{O}$ with ${ }^{1} \mathrm{H}$-succinic acid as the required hydrogen donor. The endor spectrum of the in vivo and in vitro bacteriochlorophylls is shown in FIGURE 5. Ordinarily, a peak near $18 \mathrm{MHz}$ (and $10 \mathrm{MHz}$ ) is present, however, in FIGURE 5 no such peak is visible, i.e., the peak we have designated at $\mathrm{A}_{4}$ is missing. Moreover, the peak near $16 \mathrm{MHz}$ is still present and corresponds to the peak $\mathrm{A}_{3}$.

This result confirms that the $\mathrm{A}_{3}$ peak in vivo also comes from a methyl group, because bacteriochlorophyll isolated from organisms grown in this way contains no ${ }^{1} \mathrm{H}$ at the methine positions, or at the $3,4,7,8$-proton positions, but does contain ${ }^{1} \mathrm{H}$ only at the endor-active 1 - and 5 -methyl positions. Combined with our in vitro chlorophyll $a$ data, these data make it very likely indeed that the 5-methyl group is responsible for the $A_{3}$ peak. Moreover, an in vivo resonance (FIGURE 5) near $12.8 \mathrm{MHz}$ is still present that must arise from the remaining 1 -methyl group. The absence of wings near $18 \mathrm{MHz}$ in these spectra is

TABLE 4

COMPARISON OF in Vitro AND in Vivo ENDOR DATA FOR Chl $a$ AT $-170^{\circ} \mathrm{C}$

\begin{tabular}{|c|c|c|c|}
\hline \multirow[b]{2}{*}{ Protons } & \multicolumn{2}{|c|}{$\begin{array}{c}\text { Coupling Constants } \\
\text { (MHz) }\end{array}$} & \multirow[b]{2}{*}{$\begin{array}{l}\text { Aggregation } \\
\text { Number }\end{array}$} \\
\hline & $\begin{array}{l}\text { In Vitro } \\
\mathrm{Chl}^{+} \cdot \mathrm{L}\end{array}$ & $\begin{array}{l}\text { In Vivo } \\
\text { C. vulgaris }\end{array}$ & \\
\hline Methines, $\mathrm{C}-10$ proton & .67 & $\ldots$ & $-\ldots$ \\
\hline la, $3 a$ methyls & 3.19 & & 1.9 \\
\hline 4a methylene & 3.72 & 1.68 & 2.2 \\
\hline 1a methyl & 7.42 & 3.64 & 2.0 \\
\hline 7,8 protons & 11.8 & 5.32 & 2.2 \\
\hline Average & $\ldots$ & $\ldots$ & 2.1 \\
\hline
\end{tabular}

TABLE 5

COMPARISON OF in Vitro AND in Vivo ENDOR DATA FOR BChl AT $15^{\circ} \mathrm{K}$

\begin{tabular}{|c|c|c|c|}
\hline \multirow[b]{2}{*}{ Protons } & \multicolumn{2}{|c|}{$\begin{array}{c}\text { Coupling Constants } \\
(\mathrm{MHz})\end{array}$} & \multirow[b]{2}{*}{$\begin{array}{l}\text { Aggregation } \\
\text { Number } \\
\end{array}$} \\
\hline & $\begin{array}{l}\text { In Vitro } \\
\text { BChl: } \cdot \mathrm{L}\end{array}$ & $\begin{array}{l}\text { In Vivo } \\
R \text {. rubrum }\end{array}$ & \\
\hline Methines, 10 proton & 1.4 & .84 & 1.7 \\
\hline 1a methyl & 5.32 & 2.24 & 2.4 \\
\hline 5a methyl & 9.8 & 4.76 & 2.1 \\
\hline $\begin{array}{l}3,4 \text { protons } \\
7,8 \text { protons }\end{array}$ & 14.0 & 7.0 & 2.0 \\
\hline Average & -- & --- & 2.0 \\
\hline
\end{tabular}

* Obtained by deconvolution. 
consistent with the assignment of these resonances in ${ }^{1} \mathrm{H}$-bacteriochlorophyll to the 3-, 4-, 7- and 8-protons, because this isotopically-altered culture of $R$. rubrum is fully deuterated at these positions.

Thus, these ${ }^{2} \mathrm{H}_{2} \mathrm{O}^{-1} \mathrm{H}$ succinic acid experiments with $R$. rubrum furnish direct experimental evidence to support the in vivo assignments derived from the in vitro monomer data as modified by the special pair model. We list in TABLES 4 and 5 photoreactive chlorophyll aggregation numbers based on Equation 2. Both photosynthetic bacteria and green algae show an aggregation number of essentially 2 for reaction center chlorophyll. Our special pair model is thus confirmed for the systems we have so far studięd.

\section{DISCUSSION}

We propose to discuss here some aspects of our special pair model for photoreactive chlorophyll. One of the more important features of our model is that it appears to be applicable to both green, oxygen-evolving systems as well as to purple photosynthetic bacteria. In both cases, it is important to distinguish and clearly differentiate light-harvesting antenna chlorophyll from reaction center photoreactive chlorophyll. Antenna chlorophyll constitutes the great bulk of the pigment in intact green plants and appears essentially spectroscopically inert during the act of photosynthesis. On the other hand, reaction center chlorophyll P-700 (green plants) and that part of the P-865 that is photoreactive in intact bacteria comprise only a very small fraction of the total pigment of the normal, intact photosynthetic organism and these undergo reversible photobleaching at $700 \mathrm{~nm}$ or $865 \mathrm{~nm}$ which is accompanied by esr spectral changes.

As mentioned earlier, the connection between antenna chlorophylls and in vitro forms of chlorophyll depends heavily upon optical spectroscopy. The excellent agreement between optical spectra obtained on algae in vivo and the optical spectra recorded on oligomeric chlorophyll $a,\left(\mathrm{Chl}_{2}\right)_{\mathrm{n}}$, in aliphatic hydrocarbon solvents makes it unnecessary to invoke vague chlorophyll-protein interactions to account for the optical properties of antenna chlorophyll. Experimentally, it appears that all long wavelength forms of chlorophyll, including the red-shifted forms of antenna chlorophyll, basically involve only chlorophyll-chlorophyll interactions. These chlorophyll-chlorophyll interactions arise from keto $\mathrm{C}=\mathrm{O}---\mathrm{Mg}$ interactions between chlorophyll molecules. (In the case of some photosynthetic bacteria the antenna chlorophyll seem best represented by an in vitro bacteriochlorophyll-water adduct which absorbs light with a distinct sharp peak at $865 \mathrm{~nm}$, and which also functions as photoreactive chlorophyll.) It thus appears that nature has designed the chlorophyll molecule in such a way that it is capable of self-aggregation, producing in this way oligomeric species highly suitable for extremely rapid transfer of absorbed light energy throughout the entire antenna. The efficient functioning of antenna chlorophyll requires, as far as we can see, no specific protein or lipid interactions. The role of proteins and lipids in the functioning of antenna chlorophyll may well be limited to confining the antenna chlorophyll $a$ to an hydrophobic environment.

Attached to the chlorophyll antenna is a special pair of chlorophyll molecules, in which the initial electron transfer reactions or charge separation in the primary events of light conversion in photosynthesis occur. Evidence for this special pair model is found in optical spectroscopy, apparently also by circular dichroism studies. ${ }^{43}$ However, by far the most convincing evidence for the basic 
correctness of the model results from the applications of esr spectroscopy and particularly from endor studies. The endor studies described in this communication establish that two strongly interacting chlorophyll molecules share the unpaired electron in the primary electron donor unit of photosynthesis. It is this special pair of chlorophylls that is optically bleached in the primary act of photosynthesis, and we therefore identify it with the P-700 of Kok. ${ }^{44}$ It must be emphasized that the pair of chlorophyll molecules constituting the special pair in our model is in no way to be identified as the in vitro $\mathrm{Chl} a$ dimer found in solution in nonpolar solvents. The $\left(\mathrm{Chl}_{2}\right)$ dimer first described by Closs and coworkers ${ }^{14}$ from proton magnetic resonance investigations and more recently invoked to interpret the circular dichroism studies of Houssier and Sauer ${ }^{45}$ differs basically from the chlorophyll arrangement required for the photoreactive special pair. Instead of two chlorophyll molecules in the configuration imposed by $\mathrm{C}=\mathrm{O}---\mathrm{Mg}$ forces, the special pair has a structure probably much more similar to, if not identical with, the $\left(\mathrm{Chl} \cdot \mathrm{H}_{2} \mathrm{O} \cdot \mathrm{Chl}\right)$ sandwich that constitutes the repeating unit in the chlorophyll-water adduct, $\left(\mathrm{Chl} \cdot \mathrm{H}_{2} \mathrm{O}\right)_{n}$, which absorbs light at $743 \mathrm{~nm}$. The $\left(\mathrm{Chl} \cdot \mathrm{H}_{2} \mathrm{O} \cdot \mathrm{Chl}\right)$ structure is proposed for the special pair because of the very large red shift observed in the $\left(\mathrm{Chl} \cdot \mathrm{H}_{2} \mathrm{O}\right)_{n}$ adduct, and because this structure obviously has the ability to delocalize unpaired electrons by irradiation with red light. Thus, the proposed structure has the two major properties that distinguish antenna chlorophyll from reaction center chlorophyll in green, oxygen-evolving plants.

Several possible roles exist for the water molecule in the $\left(\mathrm{Chl} \cdot \mathrm{H}_{2} \mathrm{O} \cdot \mathrm{Chi}\right)$ structure. Water may serve either as an "active" or a "passive" bridge. As an active bridge, the initial charge separation may actually occur through hydrogen abstraction from the water molecule ${ }^{26}$ followed by "hole" delocalization after the initial triplet state entity $\left(\mathrm{Chl}^{\circ}{ }^{+} \mathrm{H}_{2} \mathrm{O} \cdot \mathrm{Chl}^{-}\right)$generated by light energy has reacted with an electron acceptor. Alternatively, it is possible to conceive of the water as a passive bridge that merely holds the two chlorophyll molecules close together so that charge delocalization can occur through spin density overlap between the components of the chlorophyll special pair.

The presence of two chlorophyll molecules instead of one in the active center chlorophyll offers several interesting advantages that facilitate the primary events of light conversion in photosynthesis. To begin with, the special pair is red-shifted relative to antenna chlorophyll, particularly in the case of the green, $\mathrm{O}_{2}$-evolving plants. Thus, the special pair is a sink for the excitation energy channeled by antenna chlorophyll. Again, the special pair serves as a redox trap, i.e., $\left(\mathrm{Chl}^{+} \cdot \mathrm{H}_{2} \mathrm{O} \cdot \mathrm{Chl}\right)$ is not expected to be able to oxidize antenna chlorophyll. We have previously established that the $743 \mathrm{~nm}$ water adduct $\left(\mathrm{Chl} \cdot \mathrm{H}_{2} \mathrm{O}\right)_{n}^{+}$ cannot oxidize oligomeric $\left(\mathrm{Chl}_{2}\right)_{\mathbf{n}}$ chlorophyll. Thus, the special pair we postulate has an arrangement that effectively localizes the oxidized chlorophyll until it can be reduced by some electron donor normally present in small concentrations, thus making the process that prevents chemical or photochemical damage to chlorophyll highly efficient.

Another consequence of two-chlorophyll-molecule participation in the primary photo-act is that it greatly facilitates the interpretation of triplet spectra in photosynthesis. It is easily possible that initial electron transfer occurs within the special pair to form $\left(\mathrm{Chl}^{+} \cdot \mathrm{H}_{2} \mathrm{O} \cdot \mathrm{Chl}-\right)$; such an entity would be expected to have the esr spectrum of a triplet. A triplet signal has been recently observed by Dutton, Leigh, and Siebert ${ }^{46}$ in photosynthetic bacteria. We know that the reaction center chlorophyll must interact with the following three groups of substances: (1) antenna chlorophyll; (2) an electron acceptor, Y; and (3) an 
electron donor, $\mathrm{X}^{-}$. Two chlorophyll molecules in the active center acting in concert provide better opportunities for chlorophyll interaction with these three groups than can one chlorophyll molecule. Thus, the undesirable back reaction between the reduced electron acceptor, $\mathrm{Y}^{-}$, and the oxidized electron donor, $\mathrm{X}$, may be minimized because these two groups can be maintained a further distance apart when two chlorophyll molecules are involved as compared to a single chlorophyll molecule model. We will return to this point again when we discuss the role of protein in our model.

Our model of the photosynthetic unit that combines antenna and reaction center chlorophyll can be summarized in the following scheme. (The scheme is illustrated for Chl a systems, but one similar in principle exists for bacteriochlorophyll systems as well.)

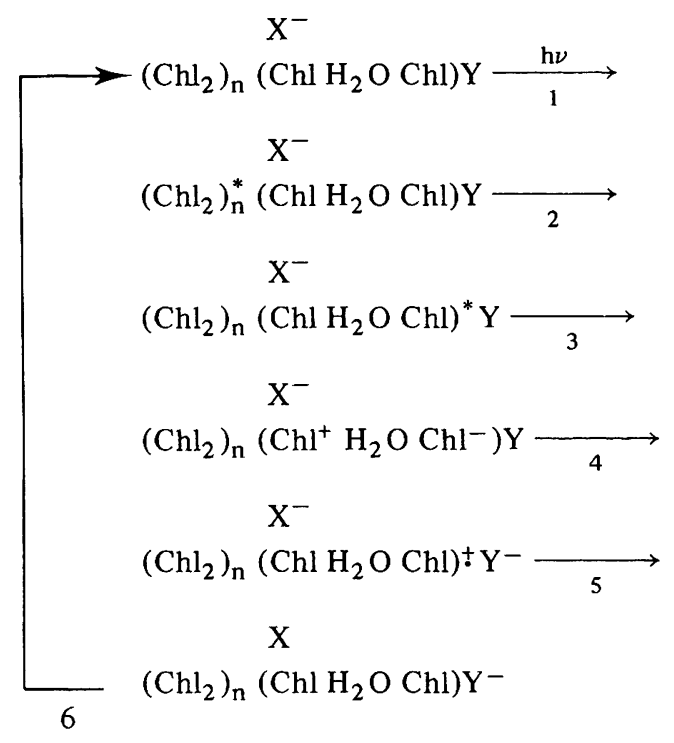

Step 1 describes the absorption of light by the antenna chlorophyll. In Step 2, excitation energy is transferred to the special pair, which undergoes in Step 3 the primary electron transfer from one chlorophyll to the other to produce a triplet radical pair. This triplet then transfers an electron in Step 4 to some electron acceptor, $\mathrm{Y}$, forming $\mathrm{Y}^{-}$. The initial chlorophyll state is restored in Step 5 by reduction of the oxidized special pair by an electron donor, $\mathrm{X}^{-}$, using an electron that originates ultimately in water.

The chlorophyll model does not specifically take into account results of others 47 which are taken to indicate, in addition to a special pair of bacteriochlorophyll molecules, the presence of two molecules of a form of bacteriochlorophyll absorbing at $810 \mathrm{~nm}$, and two bacteriopheophytin molecules in reaction center preparations from photosynthetic bacteria. Although our model does not include or require such features, it does not exclude them. It is not clear to us at this time, however, that any essential role in reaction center behavior is played by these additional pigments, particularly in intact organisms, nor is there convincing evidence that the bacteriopheophytin is not an artifact of reaction centers preparation. 
As to the role of protein in our model, we confess to iconoclastic views. Our model requires the antenna chlorophyll $a$ to exist in an hydrophobic environment, one from which water, in fact, is rigidly excluded. Proteins (in the form of the thylakoid membrane) probably constitute the barrier that preserves the antenna chlorophyll from attack by water present in the aqueous regions of the chloroplast or cytoplasm. The proteins required for electron transport into and out of the reaction center are presumably part of this protein membrane. The two electron conduits thus are physically separated, insulated so to speak, from each other, and so back a direct reaction between $\mathrm{X}$ and $\mathrm{Y}^{-}$are minimized. In our view, however, it seems very unlikely that protein plays any significant part in determining the orientation of chlorophyll molecules relative to each other in the antenna. We remind the reader once again of the remarkable similarity between the visible absorption spectrum of antenna chlorophyll in green plants and that of a concentrated, dry, solution of chlorophyll $a$ in aliphatic hydrocarbon solvents, prepared in the total absence of protein. Likewise, most of the spectral properties of photosynthetic purple bacteria can be simulated in systems consisting only of bacteriochlorophyll, with or without water, in aliphatic hydrocarbon solvents. Analogs between porphyrin-protein interactions, as in hemoglobin, and presumed chlorophyll-protein interactions in the photosynthetic apparatus seem to us to be forced, and not to be required by the experimental evidence. We cannot exclude a matrix role for protein in the operations of the reaction center itself, but here also, if we are truly parsimonious in our hypotheses, we would not invoke protein participation in explaining the optical and magnetic resonance properties of photoreaction chlorophyll at this time. At the risk of tedium, we remind the reader once again that the overwhelming body of evidence is in favor of the view that only the juxtaposition of chlorophyll molecules is required for spectral red-shifts, and that the magnitude of these and the photoactivity of the species so engendered appear to be determined entirely by chlorophyll-chlorophyll and chlorophyllwater interactions. ${ }^{24}$

We conclude, therefore, by expressing our belief that the model we describe here accounts for most of the important features of the primary act in both bacterial and green plant photosynthesis.

\section{REFERENCES}

1. EMERSON, R. \& W. ARNOLD. 1932. J. Gen. Physiol. 15: 391; 16: 191.

2. CLAYTON, R. K. 1971. Adv. Chem. Phys. 19: 353-378.

3. CLAYTON, R. K. 1973. Ann. Rev. Biophys. Bioeng. 2: 131-156.

4. CLAYTON, R. K. \& R. T. WANG. 1971. Methods Enzymol. 23: 696.

5. FEHER, G. 1971. Photochem. Photobiol. 14: 373.

6. REED, D. W., D. RAVEED \& H. W. ISRAEL. 1970. Biochim. Biophys. Acta 223: 281.

7. LOACH, P. A., D. C. SEKURA, R. M. HADSELL \& A. STEMER. 1970. Biochemistry. 9: 724.

8. OGAWA, T. L., L. P. VERNON \& H. H. MOLLENHAUER. 1969. Biochim. Biophys. Acta 172: $216-229$.

9. KATZ, J. J. \& K. BALLSCHMITER. 1968. Angew. Chem. 80: 283; Angew. Chem. Int. Ed. Engl. 7: 286.

10. BALLSCHMITER, K. \& J. J. KATZ. 1969. J. Amer. Chem. Soc. 91: 2661.

11. BALLSCHMITER, K. \& J. J. KATZ. 1972. Biochem. Biophys. Acta 256: 307. 
12. KATZ, J. J., R. C. DOUGHERTY \& L. J. BOUCHER. 1966. In The Chlorophylls. L. P. Vernon and G. R. Seely, Eds. Chapt. 7: 185-251.

13. KATZ, J. J., G. L. CLOSS, F. C. PENNINGTON, M. R. THOMAS \& H. H. STRAIN. 1963. J. Amer. Chem. Soc. 85: 3801.

14. CLOSS, G. L., J. J. KATZ, F. C. PENNINGTON, M. R. THOMAS \& H. H. STRAIN. 1963. J. Amer. Chem. Soc. 85: 3809.

15. KATZ, J. J. \& T. R. JANSON. 1972. Ann. N.Y. Acad. Sci. 206: 579-603.

16. KATZ, J. J., T. R. JANSON, A. G. KOSTKA, R. A. UPHAUS \& G. L. CLOSS. 1972. J. Amer. Chem. Soc. 94: 2883.

17. KATZ, J. J., K. BALLSCHMITER, M. GARCIA-MORIN, H. H. STRAIN \& R. A. UPHAUS. 1968. Proc. Nat. Acad. Sci. USA 60: 100.

18. NORRIS, J. R., M. E. DRUYAN \& J. J. KATZ. 1973. J. Amer. Chem. Soc. 95: 1680.

19. BALLSCHMITER, K., K. TRUESDELL \& J. J. KATZ. 1969. Biochem. Biophys. Acta 184: 604.

20. SVEC, W. A., D. RICE \& J. J. KATZ. To be published.

21. COTTON, T. M., K. BALLSCHMITER \& J. J. KATZ. 1973. Biochem. Biophys. Acta In press.

22. KATZ, J. J. 1968. Dev. Appl. Spectroscopy 6: 201.

23. SHERMAN, G. and E. FUJIMORI. 1969. Arch. Biochem. Biophys. 130: 624 .

24. KATZ, J. J. 1972. In Inorganic Biochemistry. G. Eichhorn, Ed. Chapt. 29. Elsevier Publishing Co. New York, N.Y.

25. HAMMOND, G. S. \& N. J. TURRO. 1963. Science 142: 1541.

26. GARCIA-MORIN, M., R. A. UPHAUS, J. R. NORRIS \& J. J. KATZ. 1969. J. Phys. Chem. 73: 1066.

27. ZUNDEL, G. \& A. MURR. 1967. Z. Phys. Chem. 54: 49.

28. NAKAMURA, S. \& S. MEIBOOM. 1967. J. Amer. Chem. Soc. 89: 1765.

29. BALLSCHMITER, K. \& J. J. KATZ. 1968. Nature 220: 1231.

30. KATZ, J. J. \& J. R. NORRIS. 1973. In Current Topics in Bioenergetics. D. R. Sanadi \& L. Packer, Eds. Vol. 5: 41-75. Academic Press. New York, N.Y.

31. KATZ, J. J. 1973. Naturwissenschaften 60: 32-39.

32. COMMONER, B., J. J. HEISE \& J. TOWNSEND. 1956. Proc. Nat. Acad. Sci. USA 42: 710.

33. WEAVER, E. C. 1968. Ann. Rev. Plant Physiol. 19: 283.

34. KOHL, D. H. 1972. In Biological Applications of Spin Resonance. H. M. Swartz, J. R. Bolton \& D. C. Borg, Eds.: 213-264. Wiley-Interscience. New York, N.Y.

35. NORRIS, J. R., R. A. UPHAUS, H. L. CRESPI \& J. J. KATZ. 1971. Proc. Nat. Acad. Sci. USA 68: 625 .

36. FEHER, G., A. J. HOFF, R. A. ISAACSON \& J. D. McELROY. 1973. Biophys. Soc. Abstracts. 61 a.

37. FEHER, G. 1956. Phys. Rev. 103: 834.

38. McCONNELL, H. M. 1956. J. Chem. Phys. 24: 632.

39. PENNington, F. C., H. H. STRAin, W. A. SVEC \& J. J. KATZ. 1964. J. Amer. Chem. Soc. 86: 1418.

40. FAJER, J., D. C. BORG, A. FORMAN, D. DOLPHIN \& R. H. FELTON. 1970. J. Amer. Chem. Soc. 92: 3451.

41. FAJER, J., D. C. BORG, A. FORMAN, R. H. FELTON, D. DOLPHIN \& L. VEGH. Proc. Nat. Acad. Sci. USA. In press.

42. DOUGHERTY, R. C., H. L. CRESPI, H. H. STRAIN \& J. J. KATZ. 1966. J. Amer. Chem. Soc. 88: 2854.

43. PHILliPSON, K. D., V. L. SATO \& K. SAUER. 1972. Biochemistry 11: 4591.

44. KOK, B. 1959. Plant Physiol. 34: 184.

45. HOUSSIER, C. \& K. SAUER. 1970. J. Amer. Chem. Soc. 92: 779.

46. DUTTON, P. L., J. S. LEIGH \& M. SEIBERT. 1972. Biochem. Biophys. Res. Comm. 46: 406.

47. STRALEY, S. C., W. W. PARSON, D. C. MAUZERALl \& R. K. ClAYTON. 1973. Biochem. Biophys. Acta. 305: 597. 


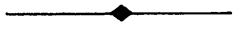

\section{DISCUSSION}

DR. G. PALMER (University of Michigan, Ann Arbor, Mich.): You have very large matrix endor signals while Dr. Feher's were either very small or nonexistent. Why is that?

DR. NORRIS: We use low frequency modulation and he uses high. Dr. Feher also says it depends on how he freezes his samples. We avoid that problem by use of deuterated solvents.

DR. WEISS: Have there been any CD studies on any of these aggregate structures in vitro?

DR. NORRIS: Not yet, except for the chlorophyll dimer in $\mathrm{CCl}_{4}$. 